\title{
The Practice of Implementing Aqiqah by Buying Ready Stock in Bajenis Subdistrict, Tebing Tinggi City in the View of Syafi'i's School
}

\author{
Muhammad Syukri Albani Nasution', Ramadhan Syahmedi Siregar ${ }^{2}$, Nurul Arif El \\ Hakim $^{3}$ \\ ${ }^{1,2,3}$ Universitas Islam Negeri Sumatera Utara, Indonesia \\ syukri_albani@yahoo.co.id
}

\begin{abstract}
The aim of this study to find out the practice of implementing Aiqaah by buying ready stock in Bajenis district. The approach used in this study is a qualitative approach. The result of the study shows that there is no intention of aqiqah at the time of slaughtering animals. Meanwhile, according to the Syafi'i mazhab, when the aqiqah animal is slaughtered, it must be intended for the aqiqah of the child. Communities in Bajenis district does not know anything about the shape of the aqiqah animal, whether the meat of the animal purchased in the market has a defect or not. Meanwhile, according to the Syafi'i mazhab, aqiqah animal must be protected from disgrace or disability. Regarding the problem of the dose of aqiqah animal, the community in Bajenis district, no longer refer to Islamic rules especially according to the Syafi'i school of thought and it is not known whether the meat comes from the same animal or has been mixed with other animal meat which is also sold by the market traders. In addition, it is not known whether the animal is old enough or not. Meanwhile, according to the Shafi'i school, the measure of aqiqah animal is two for boys and one for girls and if the animal is a camel, then it is at least five years old, if the animal is a cow, then at least two years old, if the animal is a goat, then at least one year old.
\end{abstract}

Keywords

Karofolklore; local wisdom

educational value

\section{Introduction}

Al-Quran is a revelation by Allah to the Prophet Muhammad through the Angel Jibreel, to be conveyed to Muslims, and the Al-Qur'an is as a guide and rule of life for Muslims that are historical and normative. Not all of the verses of the Al-Qur'an that are historical and normative can be understood only textually, because many of the verses of the Al-Qur'an still have broad (universal) meanings and need to be interpreted deeper, so that a law or wisdom that can be understood and practiced by all humans in general and Muslims in particular.(Habullah, 2019)

Aqiqah is one of the teachings of Islam that was exemplified by the Prophet Muhammad. Aqiqah contains wisdom and positive benefits that we can learn from it. It is carried out on the seventh day of the birth of a baby, and the aqiqah is sunnah muakad (approaching mandatory), even some scholars say it is obligatory. Every parent longs for children who are pious, devoted and channel happiness to both parents. Aqiqah is one of the important events to instill spiritual values in children who are still pure. With aqiqah, it is hoped that the baby will gain strength, physical and mental health. Cultivate and develop physically and mentally with divine values. Rasulullah SAW said: 




Meaning: "Every new born child is pawned by his aqiqah who is slaughtered in his name on the seventh day of his birth, shaved and given a name."

Aqiqah is an effort to redeem our children who are mortgaged. Aqiqah is also a realization of our gratitude for grace, as well as a mandate that Allah has given us. Aqiqah is also an effort for us to revive the sunnah of the Prophet Muhammad, which is a commendable act, considering that at this time the sunnah is rarely practiced by Muslims.

According to the scholars, the etymological definition of aqiqah is the hair of a baby's head that grows from birth. As for knowing the meaning of aqiqah in terms of syara ', the authors include the following opinions of scholars;

1. According to Sayyid Sabiq, Aqiqah is a slaughter that is slaughtered for a newborn child.

2. According to Imam Taqiyuddin Abu Bakr bin Muhammad Al-Husaini, Aqiqah is the name of something that was slaughtered on the seventh day, namely the day of shaving his head which is called Aqiqah by mentioning something connected with that name.

3. According to the jumhur of scholars, it means that aqiqah is slaughtering an animal on the seventh day of the birth of a child, both boy and girl.

Basically aqiqah has many similarities with qurban including similarities in terms of the types of animals. So just as the types of animals used for qurban purposes, the types of animals used for aqiqah usually choose between four types, namely:

1. Goats

This type of goat is often mentioned in several hadiths. According to some opinions among scholars of the Syafi'I school of thought, using a goat will be more effective than other animals.

2. Sheep

This type was used by the Prophet Muhammad, when he gave his grandchildren Hasan and Husain.

3. Cows

In some sense it is not emphasized that aqiqah must use goats. But if it is related to qurban, then aqiqah can use other animals such as cows.

4. Camels

Thus, the types of animals that can be used for the purposes of aqiqah. By knowing the types, parents can choose which type of animal best suits their economic abilities.

In this case, the researcher saw a problem that needed to be researched, because according to researchers the aqiqah procedure carried out by the community had deviated from what was taught in Islam. And because there are still many people who do not know about the aqiqah procedure and its laws, the author is interested in studying and analyzing this phenomenon in the form of a thesis entitled: "The Practice of Implementing Aqiqah by Buying Ready Stock in Bajenis Subdistrict, Tebing Tinggi City in the View of Syafi'i's School", to serve as a guide for the Muslim community in Tebing Tinggi city who will carry out aqiqah, and apply it in the community's life itself, so that they automatically realize their shortcomings. 


\section{Review of Literatures}

\subsection{Aqiqah According to Mazhab Syafi’i}

\section{a. Definition of Aqiqah}

The Qur'an, which forms the basis of all Islamic law, firmly states that Allah is the owner of everything in the world, while humans are the Khalifah of Allah on earth. Allah created everything not for Himself, but submitted to humans as caliphs on earth. According to M.A. Mannan, all human beings collectively are allowed to own, enjoy and transfer the wealth that is recognized and maintained in Islam.(Martinelli, 2019).

\section{على رأس الو لا حين ولا دته, و شرعا: ما يذ بح عند وهى لغة : الشعر الذى

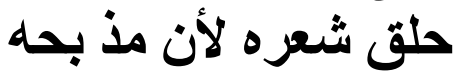

Meaning: "According to the language: aqiqah is the hair that is on the head of a newborn child. Meanwhile according to syara ': aqiqah is an animal that is slaughtered when cutting its hair because it is slaughtering".

\section{ما يذ بع عندحلق شعره شعر رأس المولودحين ولا دته, و شرعا وهى لغة

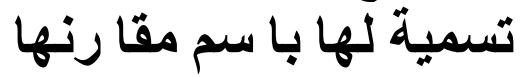

Meaning: "According to language, aqiqah is the hair on the head of a newborn child. Meanwhile, according to syara ', that is an animal that is slaughtered when cutting its hair and giving a name to it with the name ,"

\section{قال المصنف رحمه الله: العقيقة سنة وهو ما يذبح عن المو لود}

Meaning:"Saying mushannif is blessed by Allah for him: aqiqah is the law of sunnah, namely slaughtering animals from birth".

The jumhur scholars say that aqiqah is the slaughter of an animal on the seventh day of the birth of a boy or a girl.

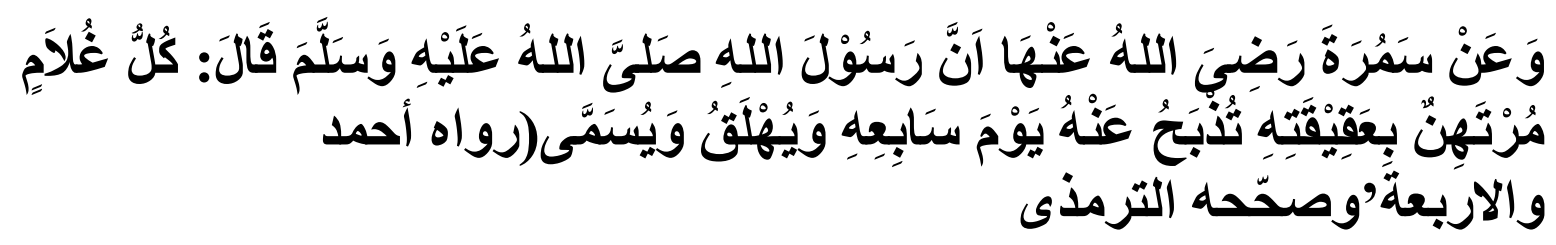

Meaning: "From Samurah r.a he said: Bahwasannya Rasulullah SAW. Said: Every baby is pawned with his aqiqah, which is slaughtered on the seventh day (of his birth), and on that day he has his head shaved and given a name. "(Imam Ahmad and Imam Four).

This hadith implies a clear understanding of aqiqah, namely animals that are slaughtered as a ransom for the authenticity of the inner relationship between parents and 
children. And the slaughter was carried out on the seventh day of the birth of the child at the same time as shaving his head and giving a name for him.

From some of the definitions above, the meaning of aqiqah is simply a series of activities for the birth of a child by slaughtering an animal which is carried out on the seventh day, and then the meat is donated to the poor along with shaving the child's hair and giving his name.

\section{b. Aqiqah Law}

Islamic inheritance law basically applies to Muslims everywhere in the world.4 Islamic inheritance law is a law that regulates all matters relating to the transfer of rights and / or obligations on one's property after he/she dies to his/her heirs.5 Islamic inheritance law is also called faraidh law, plural of the word faridha, very closely related to the word fardh which means obligations that must be implemented (Zuhirsyan, 2019). The Aqiqah law in Al-Quran are :

\section{قال المصنف رحمه الله تعا لى: العقيقة سنة}

Meaning: "Saying mushannif bless Allah for him: aqiqah is the law of circumcision".

\section{والمعنى فيه اظهار البشروالنعمة و نشر النسب, وهي سنة مؤكدة}

Meaning: "This means that humans are happy with the blessings of having offspring, the law is circumcision muakkad"

In the books of fiqh Syafi'I it is always stated that the law of aqiqah is Sunnah. It means for Muslim parents, especially those who are able, that the act of chanting is an act that is very liked by Allah SWT and is very good, because this also proves their love for their children. And by mengaqiqahkan their children, they will get reward with Allah SWT.

The Prophet SAW said:

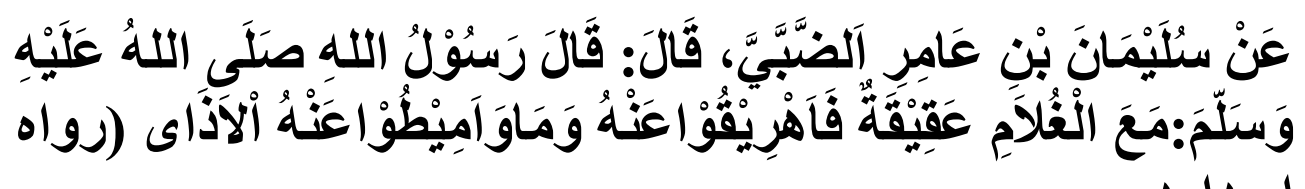

Meaning: "From Sulaiman Bin Amir Adh-Dhabi said:" Rasulullah SAW said: Along with the child there is the right to be diaqiqahi, so shed blood for him (by slaughtering aqiqah animal) and get rid of the disease from him (by shaving his head). "(Narrated by Abu Dawud)

The death of Aisyah r.a (wife of the Prophet Muhammad) also determined:




Meaning:'It was from Ayesha that Rasulullah SAW ordered people to slaughter aqiqah for a boy, two goats and a goat for a girl." (HR. Turmudzi)

Based on the explanation of the hadith above, it seems clear that the law of mengaqiqah children is Sunnah and recommended. This is according to most Imams and fiqh experts. This means that even though Rasulullah SAW did not classify them into the obligatory orders, he always carried them out. Never ignore it or only do it occasionally on a regular basis.

\section{c. Implementation Time}

\section{الغلام مرتهن بعقيقته, تذبح عنه يوم السا بع , ويحلق رأسه ويسم}

Meaning: "The child was pawned with his aqiqah, his aqiqah was slaughtered on the seventh day, and his hair was shaved and given a name".

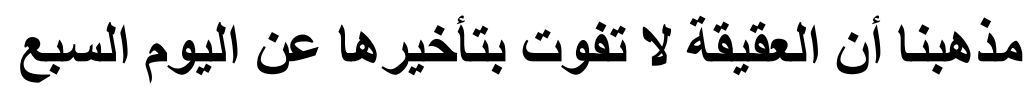

Meaning: "Our school (Mazhab Syafi'i), that aqiqah is not established by the end of the seventh day of birth".

\section{لومات المولود قبل السبع استحبت العقيقة عندنا}

Meaning:"If the child died before the seventh day of the Sunnah it was also to mengaqiqahkan according to our opinion".

As the opinion expressed by Imam Syafi'I, that slaughtering aqiqah may be carried out before or after the seventh day of the birth of the baby, as long as the child is not yet mature. However, An-Nawawi's opinion explains that if the baby dies before the seventh day, he must also be aqiqah.

Rasulullah SAW also said:

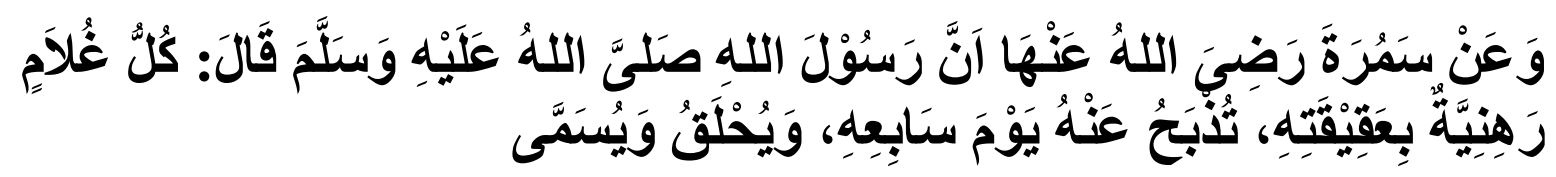

Meaning: "From Samurah r.a from Rasulullah saw, he said:" Every child is guaranteed by his aqiqah which is slaughtered on the seventh day and he is shaved and given a name. "(Narrated by Abu Daud).

Based on this hadith, it can be concluded that the slaughter of aqiqah animal is best done on the seventh day of the child's birth, while for those who have not done it, aqiqah can be done after adulthood. Aqiqah is the time since the child was born and there is no time limit. If the child has reached puberty and his aqiqah has not been done, then it is Sunnah that he does it himself.

According to Abu Abdillah al-Wasyanji, as quoted by T.M Hasbi Asy-Syidieqy, if he is unable to carry out aqiqah on the seventh day, it can be carried out on the fourteenth day. However, if it is still not mapu, it can also be held on the twenty-first day. This opinion is 
shared by scholars and most people in Indonesia. If it is still not possible to do aqiqah, then it can be done at any time when it is possible.

The opinion of qaul mukhtar, namely the opinion of selected scholars from among the Syafi'I mazhab states that the aqiqah time is still valid after the seventh day of the child's birth in the following order:

a. If on the seventh day you are still unable, then aqiqah may be carried out when the mother's puerperium ends.

b. If until the postpartum period the baby's mother ends and is unable to do so, then aqiqah may be carried out until the end of the breastfeeding period.

c. If the breastfeeding period has ended and you have not been able to do it too, it is recommended that aqiqah be carried out until the child is seven years old.

d. If the age of seven for the child has passed and has not been able to chant, then he is welcome to do it before the child is an adult.

e. If the child is an adult, the Sunnah of aqiqah for the parents will fall and the child is welcome to do it himself.

\section{d. Type and Number of Animals}

Imam Syafi'I and Imam An Nawawi have the following opinion:



Meaning: "The measurement of aqiqah animal, for boys' two goats and one goat for girls, it does not have to be either male or female goats".

\section{قد ذكرناأن مذهبنا أن عن الغلام شا تين وعن الجارية شاة}

"We have mentioned in our opinion (Syafi'I School of Law) that for boys two goats and for girls one goat".

\section{مذهبنا جواز العقيقة بما تجوزبه الأضحية من الابل والبقر والغنم}

Meaning: "Our school (Mazhab Syafi'i) may be aqiqah animal as well as animal sacrifice, namely camels, cows or oxen, and goats".

Thus, the types of animals that can be used for the purposes of aqiqah. Basically aqiqah has many similarities with qurban including similarities in terms of types of animals. By knowing the types, parents can choose which type of animal best suits their economic abilities.

Most scholars argue that all animals that are made into sacrificial animals, namely: camels, cows, buffaloes, goats, and sheep can also be used as aqiqah animals. However, according to the Maliki School, Aqiqah's animals are only goats and sheep. The other fuqaha followed the basic rule, namely that the camel is superior to the cow, and the cow is more important than the goat.

However, Imam Syafi'I once said: Yahya bin Said has reported to us from Muhammad bin Ibrahim bin Al-Harts At-Taimi, he said, "Aqiqah is liked even though it only slaughtered a bird. 
According to the Syafi'I mazhab it is permissible to aqiqah with camels and ox / buffalo as well as aqiqah with goats. In the book Majmu 'Syarah al-Muhazzab, Imam Nawawi said:

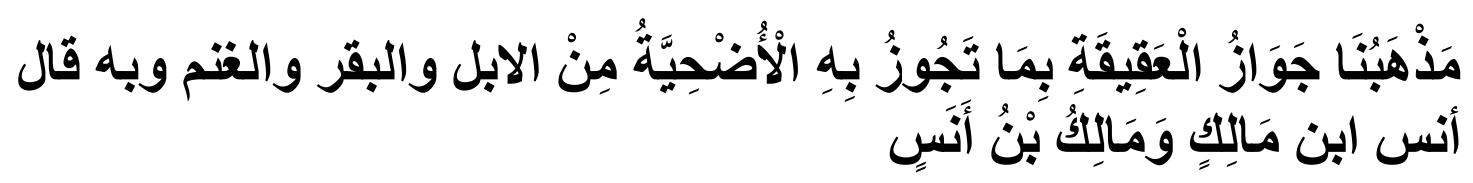

Meaning: "Our school (Mazhab Syafi'i) cans aqiqah with animals that are allowed on qurban, namely camels, oxen and goats. This opinion is also the opinion of Anas bin Malik and Malik bin Anas."

Based on the texts in the book of fiqh Syafi'I above, it can be understood that the ability of aqiqah with camels and oxen is because it is attributed to animals that are slaughtered on qurban. As it is understood that the law of aqiqah is often equated with qurban in syara '. In accordance with the words of the Prophet SAW. As follows:

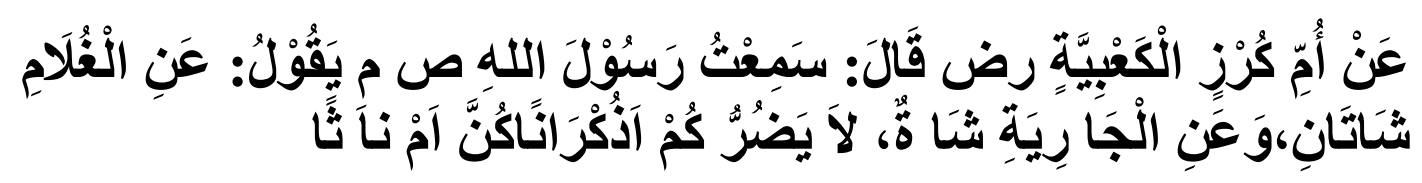

Meaning: "From Ummul Kurz Al Ka'biyah r.a he said: I once heard Rasulullah SAW say:" For boys, two sheep of the same age are for girls one lamb. Do not make it difficult for you, whether the type of sheep is male or female "(Narrated by Mother David)

Based on the information of the hadith and the opinion of the Imam of the School mentioned above, we can take the understanding that especially for underprivileged parents, they can beat their son with just one goat. This will not reduce the value of aqiqah, as long as we are honest and don't pretend to be inadequate.

\section{e. Pillars and Terms of Aqiqah}

\section{ويشترط سلامتها من العيوب التي يشترط سلامة الاضحية}

Meaning: "It is required that the aqiqah animal is protected from disgrace or disability as required for the sacrificial animal"

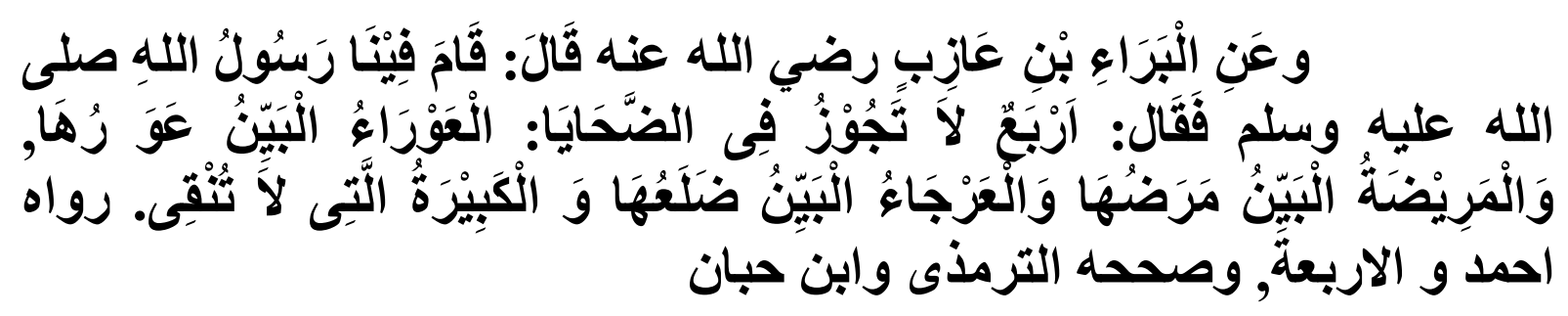

Meaning: "From Bara 'bin Azib ra he said: Rasulullah SAW once stood in the midst of us and said: four kinds of animals should not be made qurban: animals that are clearly one-sided, sick animals whose pain is clearly visible, lame animals are clearly 
visible, and an old animal that had no sum. (HR. Ahmad and Imam Empat. Sahih Hadith according to Tirmidhi and Ibn Hibban)

From the explanation of the hadith above, there are four kinds of animals that should not be used for qurban, namely one-sided animals, sick animals whose pain is clearly visible, lame animals that are clearly visible, and old animals that do not have a resource.

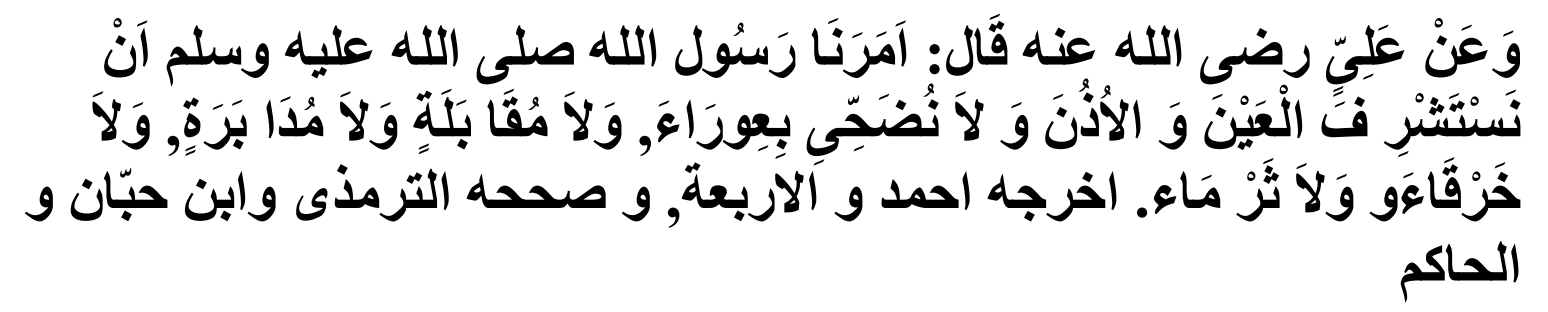

Meaning: "From Ali he said, Rasulullah SAW ordered us to inspect the eyes, ears, and we are not allowed to sacrifice to animals that are blind in one side, animals whose front ears are cut off, animals whose rear ears are cut off, animals with holes in both ears or torn off, whose front teeth are missing. " (HR. Ahmad and Imam Empat. Sahih Hadith according to Tirmidhi, Ibn Hibban, and Hakim)

From the explanation of the opinion of the Syafi'I school of thought and the hadith above, it is explained that animals for aqiqah are qiyaskan as well as animals for qurban. If there are things that must be avoided in qurban animals, then it is the same for aqiqah animal. Including the following:

a) No animals that is blind or deformed.

b) No sick animals.

c) No animal that has been lame or has broken its leg.

d) No animal whose tongue has been completely cut off.

e) No animals whose noses have been cut off.

f) No animals whose ears have been cut off.

g) No animals whose nipples are cut or dry.

h) No animal whose tail has been cut off.

Most of the scholars argue that all the animals that are slaughtered for aqiqah are the same as the animals for qurban. If it is legal for animal sacrifice to be slaughtered, this also applies to animals that are slaughtered for aqiqah. Imam Asy-Shafi'I requires that defects should be avoided in this aqiqah animal that is not allowed in qurban.

\section{f. Procedures for Aqiqah}

Imam An Nawawi wrote in his book entitled Kitab Majmu 'as follows:

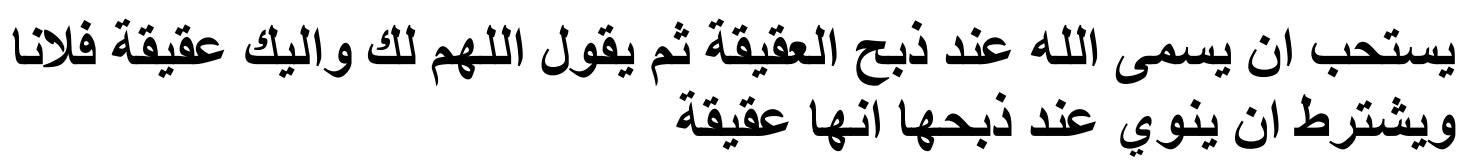

Meaning: "It is implied by changing the name of Allah when slaughtering the aqiqah animal then praying $\mathrm{O}$ Allah to you and to you aqiqah fulanan and required to intend when slaughtering aqiqah animal". 
As for animals that are slaughtered for qurban, the conditions are the same as those that are slaughtered for qurban. If the qurban meat is made to give charity before cooking, the meat of Aqiqah is circumcised to give it after cooking. As Imam An Nawawi wrote in his book entitled Kitab Majmu 'as follows:

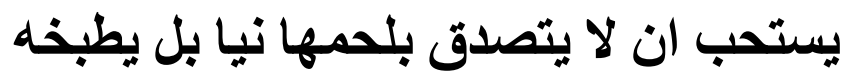

It is considered that the aqiqah meat is not donated unless it is cooked".

As with walimatul ursy and walimah circumcision in general, aqiqah party is also carried out by inviting relatives and neighbors indiscriminately. Everything must be done in an Islamic way, whether it is seating arrangements, how to dress or how to eat.

\section{Research Methods}

The starting point of the research rests on the interest in knowing social problems or phenomena that arise due to various stimuli, rather than on the research methodology. Even so, it must be remembered that research methodology is an important element in maintaining the reliability and validity of research results.

1. Approach

The approach used in this study is a qualitative approach. This is because the data required is not numeric or cannot be extrapolated.

2. Data Sources

The data sources for this study were divided into two;

a) Field research: Data obtained through qualitative field research from the Bajenis district Tebing Tinggi and other informants.

b) Library research: Data obtained through library studies and documents related to aqiqah.

\section{Result and Discussion}

\subsection{Aqiqah Practice in Bajenis District}

a. Regional Geography

\section{State of the Region}

Bajenis district, Tebing Tinggi City is one of the districts in Tebing Tinggi City, which is located east of Tebing Tinggi City. According to the data the author obtained from the Bajenis district office, the location of the Bajenis district is determined by several boundaries that separate the Bajenis district from other districts in Tebing Tinggi City, namely:

a) The West is bordered by Serdang Bedagai Regency

b) East side is bordered by Tebing Tinggi Kota District and Padang Hulu District.

c) The North is bordered by Rambutan District and Serdang Bedagai District.

d) South side is bordered by Padang Hulu District.

Bajenis sub-district has an area of 907.80 Ha consisting of seven sub-districts, namely:

a) Kelurahan Durian The area is $140.40 \mathrm{Ha}$. The head office is located at Jln. Prof. Dr. Hamka

b) Kelurahan Pelita covers 129.40 Ha. The Lurah office is located in Pelita

c) Bulian Urban Village covers $150.60 \mathrm{Ha}$. The Lurah office is located at Jl. Letda Sujono

d) Kelurahan Berohol covers 246.60 Ha. The Lurah office is located at Jln. Loyal Budi

e) Bandar Sakti Urban Village. The area is $78.10 \mathrm{Ha}$. The village head office is located at Jln. Clove 
f) Kelurahan Pinang Mancung covers $126.83 \mathrm{Ha}$. The village head office is located at Jln. Scout.

g) Teluk Karang Village with an area of 36.17 hectares. The village head office is located at Jl. Mosque

Meanwhile, the Bajenis district office itself is located at Jln. Letda Sujono.

\section{Condition of the Inhabitants}

According to sub-district statistical data, the population of Bajenis District is around 27,650 people. For more details, the authors include the condition of the population of Bajenis District according to age levels in the table below:

Table 1. Condition of Population By age

\begin{tabular}{|c|c|c|}
\hline No & Age & Total \% \\
\hline 1 & $0-6$ Year & $20,96 \%$ \\
\hline 2 & $7-10$ Year & $16,84 \%$ \\
\hline 3 & $11-16$ Year & $17,76 \%$ \\
\hline 4 & $17-55$ Year & $39,72 \%$ \\
\hline 5 & 56 Years and up & $4,72 \%$ \\
\hline \multicolumn{2}{|c|}{ Total } & $100 \%$ \\
\hline
\end{tabular}

The total population, of course they need various facilities, including education, offices and so on. In this case the author will list it in table form below:

Table 2. Office Facilities

\begin{tabular}{|c|c|c|}
\hline No & Building Name & Total \\
\hline 1 & Camat Office & 1 Unit \\
\hline 2 & KUA Office & 1 Unit \\
\hline 3 & Lurah Office & 7 Unit \\
\hline 4 & Public health center & 1 Unit \\
\hline
\end{tabular}

Apart from office facilities, there are also very dominant facilities, namely educational facilities. Adequate educational facilities will be able to support government programs in eradicating illiteracy or illiteracy, at this time, many people in Bajenis district have received education. This is evidenced by the existence of schools in the District area, with the following details:

Table 3. Education Facility

\begin{tabular}{|c|c|c|}
\hline No & Education facility & Total \\
\hline 1 & Kindergarten & 10 Unit \\
\hline 2 & Primary School & 15 Unit \\
\hline 3 & Junior High School & 5 Unit \\
\hline 4 & Senior High School & 3 Unit \\
\hline
\end{tabular}

\section{The State of the Economy}

One of the problems that is often discussed in the community is the problem of population and job vacancies. Because population problems need serious attention, both from the government and from the community itself. Of course if it is not addressed, it will have negative impacts in various sectors of life. 
As the population increases, the more job vacancies must be provided. Likewise, Bajenis district, because the population increases from year to year, those who need jobs will increase, so that the gap between job vacancies and available personnel is not appropriate.

To get closer to the author's understanding of the standard of life of the Bajenis district community, both those who have worked and those who have not, the authors include in table form below:

Table 4. Level of Community Life

\begin{tabular}{|c|c|c|}
\hline No & Profession & Total $\%$ \\
\hline 1 & Civil Servant /Employees & $16 \%$ \\
\hline 2 & Farmer & $53 \%$ \\
\hline 3 & Seller & $37 \%$ \\
\hline 4 & Fishermen / Tambak & $7 \%$ \\
\hline 5 & Labor & $17 \%$ \\
\hline 6 & And others & $2 \%$ \\
\hline & Total & $100 \%$ \\
\hline
\end{tabular}

Based on the table above, it is clear that the economy of the population of Bajenis district is generally centered on agriculture. There are also those who become employees or employees, but they also continue to farm as an additional business.

\section{State of Religion}

Humans are God's creatures which consist of a body as a real frame and a soul that cannot be measured in reality. Development of body / biological potential requires food, drink and health. Meanwhile, the development of soul / spirit potential requires correct guidance. With religion, humans will get guidance and regulations whose lives will be controlled. This is a clear orientation in religious teachings, especially Islam.

The population of Tebing Tinggi City's Bajenis district, amounting to 27,650, is mostly Muslim and others are Protestant, Catholic, Hindu, Buddhist, etc. To explain the religious condition of the people of Bajenis district, the author includes it in the form of the table below:

Table 5. The Number of Followers

\begin{tabular}{|c|c|c|}
\hline No & Religion & Total \% \\
\hline 1 & Islam & $80 \%$ \\
\hline 2 & Katolik & $8 \%$ \\
\hline 3 & Protestan & $5 \%$ \\
\hline 4 & Hindu & $3 \%$ \\
\hline 5 & Budha & $2 \%$ \\
\hline 6 & And Oher & $2 \%$ \\
\hline \multicolumn{2}{|c|}{ Total } & $100 \%$ \\
\hline
\end{tabular}

The diversity of religions practiced by the inhabitants of Bajenis district, Tebing Tinggi City is not a social problem. Even fellow religious people are reflected in the harmony of life of the religious community. This is proven that there has never been a conflict between religious communities in Bajenis district until now. They always live harmoniously side by side in accordance with government regulations because the people of Bajenis district 
practice their respective religious teachings and beliefs. Regarding the places of worship for each religion, according to the data the author obtained, it is made in a table form as follows:

Table 6. House of Worship

\begin{tabular}{|c|l|l|}
\hline No & House of worship & \multicolumn{1}{c|}{ Total } \\
\hline 1 & Mosque / Mushalla & 33 Unit \\
\hline 2 & Church & 15 Unit \\
\hline 3 & Temple / Vihara & 3 Unit \\
\hline \multicolumn{2}{|c|}{ Total } & 51 Unit \\
\hline
\end{tabular}

\subsection{Aqiqah Practice in Bajenis District}

The people of Tebing Tinggi City, especially those in Bajenis district, are religious people, almost $80 \%$ of the people embrace Islam, but of those $80 \%$ it is certain that not $100 \%$ practice Islamic syari'at properly and correctly. Some of them understand Islam halfheartedly, in other words they understand Islam only according to their own will and ability without having strong arguments or reasons according to Islam, including one of which is the problem of aqiqah.

From the author's research in the community of Bajenis District, most of the people think that aqiqah is a must when pronouncing the child's name. Some of the underprivileged people who still want to take their children, they are not looking for animals that will be aqiqah for their children, such as goats and other types of aqiqah animals, but they only buy some animal meat in traditional markets then cook it at home and give alms. They do not know whether it is goat meat, or beef, which is important for them to give alms in the name of aqiqah for the child.

Among the Muslim community in the Bajenis district who carry out aqiqah in this way are:

1. The couple Mr. Ruslan Purba and Mrs. Winda Khairani, have their first child named Nur Humairoh Purba.

In the results of the interview, the resource person explained about the aqiqah that he knew, which is a form of our gratitude to Allah SWT for the birth of a child by slaughtering animals such as goats which are donated to the poor. Then the author also asks, more practically, people choose animals for aqiqah not by slaughtering the animals themselves but buying them at the market without looking at the concept of aqiqah for one girl and for two boys. How do you respond to aqiqah by buying meat at the market? The informant answered, According to him, it was fine, when his intention was to carry out aqiqah, but due to inadequate economic conditions, he chose to buy meat at the market instead of buying live goats for qiqah. Then he also said, buying animals in the market is also not haram, and the essence of aqiqah is also cooking meat intended for the aqiqah of the child which is then donated to the poor or relatives.

\subsection{Review of Mazhab Syafi'I on Practice}

a. Overview of the Shafi'I Schools of the Process of Choosing Aqiqah Animals

From the practice of implementing aqiqah carried out by the Muslim community in Bajenis district, the author sees several procedural errors regarding the process of selecting aqiqah animals. Among others are:

\section{1) Unclear Source of Aqiqah Meat}


The procedures for the implementation of aqiqah carried out by the Muslim community in the district. This type of clothing, here the author does not see whether the meat purchased by the person who wants to eat aqiqah comes from the same animal or has been mixed with other animal meats that the merchant is selling to buy and sell. Meanwhile, according to the Syafi'I School, aqiqah for boys is two and for girls is one tail.

\section{قد ذكرناأن مذهبنا أن عن الغلام شـا تين وعن الجا رية شاة}

Meaning: "We have already mentioned in your opinion that for boys two goats and for girls one goat".

From the explanation above, which the author quotes from the book of the Shafi'I School, it is explained that the animals for the aqiqah for boys are two and for girls is one tail. And all of the animal's limbs must be completely intact. Should not be mixed with other animal meat. It's the same as sacrificial animals.

\section{2) Determining the Age of Aqiqah Animals}

With the procedure for buying animal meat in traditional markets carried out by people in the district. Bajenis, then automatically the parents who want to observe aqiqah for their children do not know whether the meat they buy in the market is old enough or not as a condition to be used as aqiqah animal. This is because the slaughterhouse or the traders who slaughter animals do not look at the age of the animal to be slaughtered. They only saw whether the animal to be slaughtered was big enough even though it had not reached its age, and the number of requests from buyers. Meanwhile, according to the Syafi'I School, animals that are allowed to be slaughtered for aqiqah are the same as animals that are allowed to be slaughtered for qurban, in terms of age and criteria.

a) If the animal is a camel, it must be at least five years old.

b) If the animal is a cow, it must be at least two years old.

c) If the animal is a goat, it must be at least one year old

3) Ignorance of Whether or Not There is Disgrace or Defect in the Purchased Animal Meat

With the procedures carried out by the community, it is clear that the buyer who wants to give the child's aqiqah does not know what the animal looks like before being slaughtered, whether the meat of the animal he has bought is protected from defects or not. Meanwhile, according to the Syafi'I School, the criteria for aqiqah animal are the same as the criteria for animals to sacrifice. The animal must be protected from disgrace or disability.

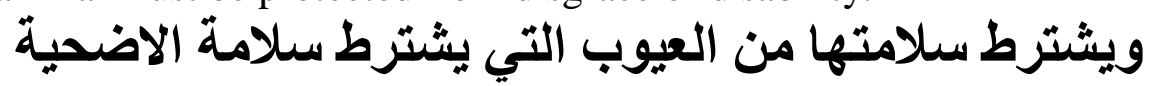

Meaning: "It is required that the aqiqah animal is protected from disgrace or disability as required for the sacrificial animal".

Based on the explanation above, it is very clear that the animal requirements for aqiqah are the same as for qurban animals. One of them is that the animal must avoid disgrace or disability. Regarding this, the author has explained in Chapter II about the disgrace or defects that must be avoided from these aqiqah animals.

\section{b. Overview of the Shafi'I School of the Aqiqah Animal Slaughtering Process}

In practice the implementation of aqiqah in the district. This type of clothing, the author sees parents who want to offer aqiqah for their children, they do not slaughter aqiqah animal. In the absence of slaughtering the animal by the person with the evil spirit, automatically 
there is no intention that is expressed at the time of the slaughter of the animal by the meat trader. Parents who want to celebrate aqiqah for their children, only buy animal meat in the market that has been cut into pieces. They also do not even know whether the meat they bought came from the same animal or was mixed with the meat of other animals that these traders were selling. Meanwhile, according to the Syafi'I mazhab, at the time of slaughtering the aqiqah animal, this is where the intention is that the animal being slaughtered is for the aqiqah of the child. As stated in the information below.



Meaning: "It is implied by changing the name of Allah when slaughtering the aqiqah animal then praying $\mathrm{O}$ Allah to you and to You aqiqah fulanan and required to intend when slaughtering aqiqah animal”.

\section{c. The Practice of Beraqiqah in Bajenis District Viewed from the Perspective of the Shafi'I School}

Based on the information in Sub A and Sub B, the author assumes that the implementation of aqiqah that is carried out by some people in Bajenis district is wrong. This is because the people in the Bajenis district do not follow the procedures for implementing aqiqah according to the Syafi'I School. Some of the mistakes are:

1. There is no intention at the time of slaughtering aqiqah animal. The people there only buy animal meat by kilo in traditional markets. Meanwhile, according to the Syafi'I mazhab, when the aqiqah animal is slaughtered, it must be intended for the aqiqah of the child.

2. Communities in Bajenis district does not know anything about the form of the aqiqah animal that is intended for the child. Whether the animals purchased in the traditional market have defects or not. Meanwhile, according to the Syafi'I mazhab, the requirement for aqiqah animal is that it must be protected from disgrace or disability.

3. Regarding the problem of the dose of aqiqah animal, the community in Bajenis district, only looking at the number of invitations during the celebration and it is not known whether the meat comes from the same animal or has been mixed with other animal meat which is also sold by the market trader. Meanwhile, according to the Syafi'I mazhab, the dose of aqiqah animal is two for boys and one tail for girls.

\section{Conclusion}

The simple meaning of aqiqah is a series of activities for the birth of a child by slaughtering an animal which is carried out on the seventh day and the meat is donated to the poor along with shaving the child's hair and giving his name.

The law of carrying out aqiqah is sunnah and recommended. Even though Rasulullah SAW did not classify them into the obligatory orders, he always carried them out. Never ignore it or only do it occasionally on a regular basis.

The procedures for aqiqah according to the Syafi'I School are:

1. Aqiqah is performed on the seventh day from the birth of the child.

2. The type of animal aqiqah is qurban.

3. The number of aqiqah animals for a boy is two and a girl is one.

4. Aqiqah animal must be protected from disgrace or disability.

5. Read bismillah and intend to aqiqah sianak at the time of slaughtering the aqiqah animal. 
6. The meat of the aqiqah animal is given in a cooked state.

From the aqiqah procedure carried out by the people of Kec. Bajenis, there are three deviations from the Shari'at of Islam (especially according to the opinion of the Shafi'I School). These three things are:

1. There is no intention of aqiqah at the time of slaughtering animals. Meanwhile, according to the Syafi'I mazhab, when the aqiqah animal is slaughtered, it must be intended for the aqiqah of the child.

2. Communities in the district. This Bajenis does not know anything about the shape of the aqiqah animal, whether the meat of the animal purchased in the market has a defect or not. Meanwhile, according to the Syafi'I mazhab, aqiqah animal must be protected from disgrace or disability.

3. Regarding the problem of the dose of aqiqah animal, the community in Kec. Bajenis, no longer refer to Islamic rules especially according to the Syafi'I school of thought and it is not known whether the meat comes from the same animal or has been mixed with other animal meat which is also sold by the market traders. In addition, it is not known whether the animal is old enough or not. Meanwhile, according to the Shafi'I school, the measure of aqiqah animal is two for boys and one for girls and if the animal is a camel, then it is at least five years old, if the animal is a cow, then at least two years old, if the animal is a goat, then at least one year old.

\section{Suggestion}

1. Government officials in charge of worship, be it the Ministry of Religion or MUI, should be able to provide a more intensive socialization of religious understanding to the Muslim community in the Bajenis district so there is no mistake in carrying out worship.

2. To the Muslim community in the Bajenis district, should deepen their understanding of their religion by learning from the religious scholars, so that there are no mistakes in carrying out worship to Allah SWT, especially aqiqah worship and worship that is not in vain before Him

\section{References}

A.K, Mujahid, Materi Pokok Fiqih II, Jakarta: Direktorat Jenderal Pembinaan Kelembagaan Islam dan Universitas Terbuka, 2000.

Ahmad, Syamsuddin Muhammad bin Abi Abbas, Nihayatul Muhtaj, Beirut: Daar Alkutub Al Ilmiyah, tt.

Al Asqalani, Ibnu Hajar, Bulughul Maram, Surabaya: Mutiara Ilmu, 2012.

Al-Hauti, Kamal Yusuf, Al-Jami Al-Sahih, Sunan al-Turmudzi Juz IV, Beirut: Dar al-Kutub al-Ilmiah, tt.

Al-Husaini, Imam Taqiyyuddin Abu Bakar bin Muhammad, Kifayatul Akhyar, Kelengkapan Orang Shaleh, Surabaya: Bina Iman, 1980.

An Nawawi, Abu Zakaria, Kitab Majmu', Beirut:Daar Ihya Atturas Al Araby, 2001.

Arikunto, Suharsimi, Prosedur Penelitian Suatu Pendekatan Praktek Cet XII, Jakarta: PT. Rineka Cipta, 2003.

Ash Shiddieqy, Teungku Muhammad Hasby, Hukum Fiqh Islam Tinjauan Antar Mazhab, Semarang: Pustaka Rizki Putra, 2001.

Ash Shiddieqy, Teungku Muhammad Hasby, Tuntunan Qurban dan Aqiqah, Semarang: Pustaka Rizki Putra, 2010.

As-Sajastani, Imam Abu Dawud Sulaiman Bin Al-Asy'ats, Sunan Abu Dawud Juz II, Beirut: Daar al-Kutub al-Ilmiah, 1996. 
Bingin, Burhan, Metode Penelitian Kualitatif, Jakarta: Raja Grafindo Persada,2008.

Departemen Agana RI, Al Qur'an dan Terjemahnya, Jakarta: CV Atlas, 2000.

Djamaluddin, H.Bey Arifin dan Syinqithy, Terjemah Sunan Abu Dawud Jilid III, Semarang: CV. Asy Syifa', 1992.

Halim, M. Nipan Abdul, Mendidik Keshalehan Anak, Akikah, Pemberian Nama, Khitan dan Maknanya, Jakarta: Pustaka Amani, 2001.

Kahlani, Muhammad Ismail, Subulussalam Juz IV, Bandung: Diponegoro, tt.

Hasbullah, et al (2019). Messages Communication in the Al-Qur'an (Study of Messages in the Al-Qur'an for Believers). Budapest International Research and Critics InstituteJournal (BIRCI-Journal) .P. 125-131

Kamus Besar Bahasa Indonesia edisi III, Jakarta: Balai Pustaka, 2002.

Khalid, Muhammad Abdul Aziz, Hawasyi, Beirut: Daar Alkutub Al Ilmiyah, tt.

Mardjoned, Ramlan, Aqiqah, Jakarta: Media Dakwah, 2002.

Martinelli, I. et al. (2019). Community Economic Development Prospect Based on Wakaf Funds. Budapest International Research and Critics Institute-Journal(BIRCI-Journal). P. 409-423

Ramayulis, dkk, Pendidikan Islam Dalam Rumah Tangga, Jakarta: Kalam Mulia, 2001.

Rifa'i, Mohammad, Ilmu Fiqih Islam Lengkap, Semarang: PT Karya Toha Putra, 2007.

Rifa'i, Muhammad dkk, Terjemah Khulashah Kifayatul Akhyar, Semarang: Toha Putra, 1978.

Sabiq, Sayyid, Fiqih Sunnah 13, Bandung: Al-Ma'arif, 1995.

Shihab, Quraish, Membumikan Al-Qur'an, Bandung: Mizan, 2003.

Syafi'i, Imam Muhammad Bin Idris, Al-Umm, Beirut: Daar Al Kutub Al Ilmiyah, 2003.

Syafi'i, Imam, Ringkasan Kitab Al-Umm, Terj. Abdullah Muhammad bin Idris, Jakarta: Pustaka Azzam, 2013.

Zainal, Amiruddin, dan H., Pengantar Metodolgi Penelitian Hukum, Jakarta: Raja Grafindo Persada, 2004.

Zuhirsyan,M. et al. (2019). Implementation of Heritage Distribution in the Community in Islamic Law Antropology Perspective (Study On Simalungun Tribe In Kuta Baru Village, Tebing Tinggi, Serdang Bedagai Regency). Budapest International Research and Critics Institute-Journal (BIRCI-Journal).P. 477-486. 